\title{
RESISTANCE TO CONTROLLED THERMAL STRESS AND TOLERANCE TO SPERM CRYOPRESERVATION OF TWO GROUPS OF BOARS
}

\author{
B. Stanković ${ }^{1}$, S. Hristov ${ }^{1}$, B. Petrujkić ${ }^{2}$, N. Delić ${ }^{3}$, N. Maksimović ${ }^{3}$, J. \\ Bojkovski ${ }^{2}$ \\ ${ }^{1}$ Faculty of Agriculture, Nemanjina 6, 11080, Belgrade-Zemun, Republic of Serbia
${ }^{2}$ Faculty of Veterinary Medicine, Bul oslobođenja 18, 11000, Belgrade, Republic of Serbia
${ }^{3}$ Institute for Animal Husbandry, Autoput 16, P. Box 23, 11080, Belgrade-Zemun, Republic of Serbia
Corresponding author: baxton@agrif.bg.ac.rs
Original scientific paper
}

\begin{abstract}
The aim of this study was to find out is it possible to presume success of boars sperm cryopreservation, based on controlled exposure to heat stress and to investigate in vitro quality parameters of frozen/thawed sperm of previously selected 6 boars with good results (group 1) and 6 boars (group 2) with bad results on thermo resistance test (TT). In this investigation, ejaculates of 12 chosen of 75 AI boars (Landrace, Large White, Pietrain and Durock breeds) from SVC Velika Plana (Serbia) were used. Tolerance to heat stress was performed by Schaetz (1963) method. Ejaculates were extended with Androhep plus (1:1) and kept during 60 minutes on $41{ }^{\circ} \mathrm{C}$. In cryopreservation of boars semen Westendorf et al. (1975) method, modified by Bwanga et al. (1990). Very significant changes of progressive motility rate were observed after spermatozoa exposure to controlled thermal stress. High correlation coefficient of progressive motility rate of both groups of boars, but higher in group 2 for progressive motility rate after thawing and after heat stress treatment was established. Average progressive motility rate of all 12 boars did not differ before and after thawing. Presence of boars of all breeds represented in the SVC (Large White, Landrace, Duroc and Pietrain) in both quality groups confirms the assumption that suitability for cryopreservation of sperm is individual trait. According data analysis, sperm deep freezing success requires previous selection for potential donors, which have to be consider standard quality parameters testing and controlled stress exposure tests.
\end{abstract}

Key words: boar, cryopreservation, progressive motility rate, sperm, thermo resistance test 


\section{Introduction}

The use of frozen/thawed boar semen makes less than $1 \%$ of all artificial insemination (AI) in swine population of the world (Wagner and Thibier, 2000). Disadvantages and limitations of frozen/thawed boar semen AI are primarily related to low fertilizing rate (40-70\%), and litter size (7-10 piglets), comparing to diluted semen inseminations (Johnson, 1985; Almlid and Hofmo, 1996).

Considering available data, it makes sense to presume that ability to preserve intact cell membrane of the boar spermatozoa in extreme low temperature shock conditions and its elasticity to bear all types of stress might be very useful in sperm cryopreservation success prediction. According to Giraud et al. (2000), human sperm cryopreservation tolerance is individual trait, directly related to cell membrane fluidity preservation; higher fluidity means higher spermatozoa survival after freezing.

The aim of this study was to find out is it possible to presume success of boars sperm cryopreservation, based on controlled exposure to heat stress and to investigate in vitro quality parameters of frozen/thawed sperm of previously selected 6 boars with good results (group 1) and 6 boars (group 2) with bad results on thermo resistance test (TT).

\section{Materials and Methods}

In order to determine basic sperm quality parameter values (ejaculate volume, $\mathrm{pH}$, sperm concentration and progressive motility rate before and after freezing and thawing) and thermo resistance of sperm, ejaculates of chosen 12 of 75 AI boars (Landrace, Large White, Pietrain and Durock) from SVC Velika Plana (Serbia) were used. Two quality groups of boars, each of 6 , were formed, according their ability to bear controlled heat stress: group $1-6$ boars with good results, and group 2 - with bad results on thermo resistance test (TT).

Thermo resistance test of ejaculates was performed by method of Schaetz (1963): in cuvette were instilled equal amounts of semen and Androhep plus extender, than heated to $38{ }^{\circ} \mathrm{C}$, and then placed in the water bath at $41{ }^{\circ} \mathrm{C}$. After 60 minutes, progressive motility rate was estimated.

Chosen boars sperm was cryopreserved by Westendorf et al. (1975), modified by Bwanga et al. (1990). This means that from sperm must be separated seminal plasma, as in any other cryopreservation boar sperm protocol, making sperm more dense, and use of cryoprotectants containing extenders and controlled regime of cooling and freezing.

Final modifications considered use of Androhep plus instead of Androhep Cryo Guard as colling extender and Tryladyl egg yolk extender as freezing extender (Minitub, Germany), empiric established holding time of 150 minutes, use of minitubes $(0,25 \mathrm{ml})$ and empiric choice of the most suitable temperature and thawing time $\left(20\right.$ seconds on $\left.+38^{\circ} \mathrm{C}\right)$. 
After thawing, progressive motility rate was estimated. Obtained data were analysed using standard statistical methods.

\section{Results and Discussion}

Using $\chi^{2}$ test to analyse data obtained in thermo resistance test of 75 ejaculates, very significant differences were found comparing progressive motility rate before and after treatment $\left(\chi^{2}=1933 ; \chi_{0,01 ; 75}^{2}=100,4\right.$, za $\left.\mathrm{P}<0,01\right)$, and two groups of chosen boars were formed.

Table 1. Thermo resistance test results, group 1.

\begin{tabular}{|c|c|c|c|c|}
\hline & $\mathrm{Hb}$ boar & $\begin{array}{c}\text { Progressive } \\
\text { motility rate (\%) }\end{array}$ & $\begin{array}{c}\text { Progressive } \\
\text { motility rate after } \\
1 \mathrm{~h}, 41^{\circ} \mathrm{c}(\%)\end{array}$ & $\underset{(\%)}{\Delta}$ \\
\hline 1. & D 60 & 90 & 90 & 0 \\
\hline 2. & J 208 & 95 & 90 & 5 \\
\hline 3. & L 1206 & 95 & 95 & 0 \\
\hline 4. & L 298 & 95 & 90 & 5 \\
\hline 5. & L 300 & 90 & 90 & 0 \\
\hline 6. & P 134 & 85 & 80 & 5 \\
\hline
\end{tabular}

According to tables 1 and 2, progressive motility rate was decreased in both groups, particularly in group 2 .

Table 2. Thermo resistance test results, group 2.

\begin{tabular}{|c|c|c|c|c|}
\hline & $\mathrm{Hb}$ boar & $\begin{array}{c}\text { Progressive motility } \\
\text { rate }(\%)\end{array}$ & $\begin{array}{l}\text { Progressive motility } \\
\text { rate after } 1 \mathrm{~h}, 41^{\circ} \mathrm{c}(\%)\end{array}$ & $\begin{array}{c}\Delta \\
(\%)\end{array}$ \\
\hline 1. & J 207 & 90 & 75 & 15 \\
\hline 2. & J 217 & 75 & 45 & 30 \\
\hline 3. & $\mathrm{~L} \mathrm{40}$ & 80 & 60 & 20 \\
\hline 4. & $\underline{P 138}$ & 65 & 25 & 40 \\
\hline 5. & $\underline{\mathrm{P} 148}$ & 95 & 80 & 15 \\
\hline 6. & P 130 & 90 & 60 & 30 \\
\hline
\end{tabular}

Difference in progressive motility rate before and after heat treatment in group 1 did not appear or was smaller than 5\%, while it was 15\% (J 207 and P 148) to $40 \%$ (P 138) in group 2 .

Decrease of progressive motility rate of spermatozoa after exposure to heat was more notable in group 2.

Analysis of differences of progressive motility rate of spermatozoa decrease before and after controlled heat exposure using t-test showed its significance between groups before $(\mathrm{t}=1.870 ; \mathrm{P}<0.05)$, increasing after heat exposure $(\mathrm{t}=3.734 ; \mathrm{P}<0.01)$.

Similar results obtained Kozumplik and Sosnová (1985), and Kozumplik and Roubal (1990), recommending this method of bull and boar semen quality 
testing. Significance of the obtained differences points out that TT is simple, fast and suitable test for testing sperm resistance to heat stress.

Table 3. Basic sperm quality parameters, group 1

\begin{tabular}{|c|c|c|c|c|c|}
\hline & Boar hb & $\begin{array}{c}\text { Ejaculate } \\
\text { volume }(\mathrm{ml})\end{array}$ & $\mathrm{Ph}$ & $\begin{array}{c}\text { Progressive } \\
\text { motility rate }(\%)\end{array}$ & $\begin{array}{c}\text { Concentration (x } \\
\left.10^{6} / \mathrm{ml}\right)\end{array}$ \\
\hline 1. & $\underline{\mathrm{D} 60}$ & 280 & 7.2 & 90 & 280 \\
\hline 2. & $\underline{\mathrm{J} 208}$ & 280 & 7.4 & 95 & 290 \\
\hline 3. & $\underline{\mathrm{L} 1206}$ & 300 & 7.5 & 95 & 280 \\
\hline 4. & $\underline{\mathrm{L} 298}$ & 260 & 7.5 & 95 & 280 \\
\hline 5. & $\underline{\mathrm{L} 300}$ & 250 & 7.5 & 90 & 280 \\
\hline 6. & $\underline{\mathrm{P} 134}$ & 280 & 7.4 & 85 & \\
\hline
\end{tabular}

In table 3 and 4, basic sperm quality parameters values (ejaculate volume, $\mathrm{pH}$, progressive motility rate and spermatozoa concentration) were given, and response to technological standards.

Table 4. Basic sperm quality parameters, group 2

\begin{tabular}{|c|c|c|c|c|c|}
\hline & Boar hb & $\begin{array}{c}\text { Ejaculate } \\
\text { volume (ml) }\end{array}$ & $\mathrm{Ph}$ & $\begin{array}{c}\text { Progressive } \\
\text { motility rate (\%) }\end{array}$ & $\begin{array}{c}\text { Concentration (x } \\
\left.10^{6} / \mathrm{ml}\right)\end{array}$ \\
\hline 7. & $\underline{\underline{\mathrm{J} 207}}$ & 200 & 7.4 & 90 & 290 \\
\hline 8. & $\underline{\underline{\mathrm{J} 217}}$ & 300 & 7.4 & 75 & 290 \\
\hline 9. & $\underline{\underline{\mathrm{L} 40}}$ & 280 & 7.6 & 80 & 290 \\
\hline 10. & $\underline{\underline{\mathrm{P} 138}}$ & 380 & 6.8 & 65 & 250 \\
\hline 11. & $\underline{\underline{\mathrm{P} 148}}$ & 280 & 7.3 & 95 & 280 \\
\hline 12. & $\underline{\underline{\mathrm{P} 130}}$ & 300 & 7.6 & 90 & 280 \\
\hline
\end{tabular}

These values between groups were not significantly different (ejaculate volume $\mathrm{t}=0.610 ; \mathrm{pH}$ ejaculates $\mathrm{t}=0.510$; spermatozoa concentration $\mathrm{t}=0.50)$, except in respect of progressive motility rate $(\mathrm{t}=1.870 ; \mathrm{P}<0.05)$.

Table 5. Progressive motility rate of spermatozoa before and after cryopreservation, group 1

\begin{tabular}{|c|c|c|c|c|}
\hline & $\begin{array}{c}\text { Boar } \\
\mathrm{Hb}\end{array}$ & $\begin{array}{c}\text { Agglutination after } \\
\text { centrifuging }\end{array}$ & $\begin{array}{c}\text { Progressive } \\
\text { motility rate before } \\
\text { freezing (\%) }\end{array}$ & $\begin{array}{c}\text { Progressive } \\
\text { motility rate after } \\
\text { freezing (\%) }\end{array}$ \\
\hline 1. & L 1206 & - & 95 & 45 \\
\hline 2. & L 298 & - & 95 & 35 \\
\hline 3. & L 300 & - & 90 & 25 \\
\hline 4. & P 134 & - & 85 & 45 \\
\hline 5. & J 208 & - & 95 & 30 \\
\hline 6. & D 60 & - & 90 & 20 \\
\hline
\end{tabular}

In vitro parameter values of spermatozoa of both groups before and after cryopreservation were given in tables 5 and 6 . 
Group 1 spermatozoa showed high progressive motility rate before freezing, average $91.667 \%(85 \%$ to $95 \%)$, and after thawing $33.333 \%(20 \%$ to $45 \%$ ). Spermatozoa of this group did not showed tendency to agglutinate during centrifugation. Although average progressive motility rate before freezing of the group 2 was $82.500 \%$ (65\% to $95 \%)$, it decreased to only $19.167 \%$ (5\% to $35 \%)$ after thawing. Furthermore, spermatozoa of 4 of 6 boars of this group revealed tendency to agglutinate on the bottom of the cuvette during centrifugation, decreasing yield of spermatozoa for further cryopreservation. Progressive motility rate of spermatozoa before cryopreservation showed significant differences $(\mathrm{t}=1.87 ; \mathrm{P}<0.05)$, but it was not significant after thawing $(\mathrm{t}=2.1086 ; \mathrm{P}>0.10)$.

Progressive motility rate before freezing of spermatozoa of the group 2 varied from $65 \%$ to $95 \%$, and intensively decreased after thawing, to less than $5 \%$ to $35 \%$.

Table 6. Progressive motility rate of spermatozoa before and after cryopreservation, group 2

\begin{tabular}{|c|c|c|c|c|}
\hline & $\begin{array}{c}\text { Boar } \\
\mathrm{Hb}\end{array}$ & $\begin{array}{c}\text { Agglutination after } \\
\text { centrifuging }\end{array}$ & $\begin{array}{c}\text { Progressive motility } \\
\text { rate before freezing (\%) }\end{array}$ & $\begin{array}{c}\text { Progressive motility } \\
\text { rate after freezing (\%) }\end{array}$ \\
\hline 7. & L 40 & + & 80 & 30 \\
\hline 8. & P 130 & + & 90 & $<5$ \\
\hline 9. & P 138 & + & 65 & 15 \\
\hline 10. & P 148 & - & 95 & 25 \\
\hline 11. & J 207 & - & 90 & 35 \\
\hline 12. & J 217 & + & 75 & $<5$ \\
\hline
\end{tabular}

Relationship between progressive motility rate before and after freezing was evaluated by method of quadratic regression and strength of relationship by correlation coefficient $(\mathrm{R})$, determination coefficient $\left(\mathrm{R}^{2}\right)$. R-value for group 1 spermatozoa progressive motility rate before and after freezing was rather low $\left(\mathrm{R}=0.1988 ; \mathrm{R}^{2}=0.0175073\right)$, as well as for group $2\left(\mathrm{R}=0.3283195 ; \mathrm{R}^{2}=0.1077937\right)$.

High correlation coefficient of progressive motility rate of both groups of boars, but higher in group 2 for progressive motility rate after thawing and after heat stress treatment was established $\left(\mathrm{R}=0.83046\right.$ and $\mathrm{R}^{2}=0.689672 ; \mathrm{R}=0.95420$ and $\mathrm{R}^{2}=0.9105016$, respectively) but slightly higher for the group 2 . Obtained data were consistent with the findings of Kozumplik and Sosnova (1985) and Kozumplik and Roubal (1990), but were not with data presented for bull sperm presented by Vianna et al. (2009), although these were related to low correlation level to conception.

During investigations, several different types of deviations ih shape and movement of spermatozoa were recognised, such as swelling, coiled tail spermatozoa, or circling.

Presence of boars of all breeds represented in the SVC (Large White, Landrace, Duroc and Pietrain) in both quality groups confirms the assumption that suitability for cryopreservation of sperm is individual trait, which was consistent to 
findings of Schilling and Vengust (1987), and Thurston et al. (2002), who established genetic conditioned differences in sperm quality of boars, as well as humans (Giraud et al., 2000).

Obtained data showed that the highest losses in spermatozoa survival happens during freezing and thawing, with consequent decrease of progressive motility rate and cell membrane damages, according several authors (Paulenz et al., 1995; Huang et al., 1999; Ericsson, 2000; Holt, 2000).

\title{
Conclusion
}

According obtained data analysis, it could be concluded that:

- Thermo resistance test revealed significant changes of progressive motility rate of spermatozoa after exposure to controlled heat stress.

- High correlation coefficient of progressive motility rate of both groups of boars, but higher in group 2 for progressive motility rate after thawing and after heat stress treatment was established.

- Average progressive motility rate of all 12 boars did not differ before and after thawing.

- Presence of of boars of all breeds represented in the SVC (Large White, Landrace, Duroc and Pietrain) in both quality groups confirms the assumption that suitability for cryopreservation of sperm is individual trait.

- According data analysis, sperm deep freezing success requires previous selection for potential donors, which have to be consider standard quality parametars testing and controlled stress exposure tests.

\section{Acknowledgment}

Research was financed by the Ministry of Science and Technological Development, Republic of Serbia, projects TR 20110 and TR 31053.

\section{Otpornost na kontrolisani termalni stres i tolerancija na zamrzavanje spermatozoida dve grupe nerastova}

\author{
B. Stanković, S. Hristov, B. Petrujkić, N. Delić, N. Maksimović, J. Bojkovski
}

\section{Rezime}

Cilj rada je da se ustanovi da li moguće odrediti da li je sperma nerasta pogodna za krioprezervaciju da se na osnovu izlaganja spermatozioda 
kontrolisanom toplotnom stresu $\mathrm{i}$ da se ispitaju in vitro parametri kvaliteta odmrznutog semena dve grupe od po 6 nerastova čije je seme dobro (1. grupa) ili loše podnelo toplotni stres (2. grupa). U istraživanju su korišćeni ejakulati 12 od 75 nerastova rasa: landras, veliki jorkšir, pijetren i durok (L, J, P, D) iz SVC Velika Plana, odabranih na osnovu testa termorezistencije (TT) i svrstanih u dve kvalitetne grupe. Ispitivanje stepena termorezistencije ejakulata u razređenju Androhep-om plus 1:1 60 minuta na $41{ }^{\circ} \mathrm{C}$, je izvedeno metodom po Schaetz-u (1963). Duboko zamrzavanje sperme odabranih nerastova izvedeno modifikovanim postupkom po Westendorf-u $i$ sar. (1975) i Bwanga-i i sar. (1990). Rezultati TT ukazali su na vrlo značajne promene progresivne pokretljivosti spermatozoida posle izlaganja kontrolisanom toplotnom stresu. Ustanovljen je visok koeficijent korelacije kod obe grupe ali ipak nešto viši kod nerastova 2. grupe za odnos procenta progresivne pokretljivosti spermatozoida posle odmrzavanja i progresivne pokretljivosti posle izlaganja temperaturi od $41^{\circ} \mathrm{C}$. Prosečna progresivna pokretljivost spermatozoida svih ispitivanih nerastova se nije značajno razlikovala pre i posle zamrzavanja. Slučajni raspored nerastova svih rasa zastupljenih u SVC (Jorkšir, Landras, Durok i Pijetren) u obe kvalitetne grupe potvrđuje pretpostavku da je pogodnost sperme za krioprezervaciju individualna osobina. Za uspešnu krioprezervaciju sperme nerastova je neophodna prethodna selekcija potencijalnih donora na osnovu rezultata ispitivanja standardnih parametara kvaliteta i testova u kojima se spermatozoidi in vitro izlažu različitim kontrolisanom stresu.

\section{References}

ALMLID T., HOFMO P.O. (1996): A brief review of frozen semen application under Norwegian A1 service conditions. Reprod. Dom. Anim., 31, 169-173.

BWANGA, C.O., DE BRAGANCA, M.M., EINARSSON, S. RODRIGUEZMARTINEZ H. (1990): Cryopreservation of boar semen in mini- and maxi-straws. J. Vet. Med. A., 31, 651-658.

ERIKSSON, B. (2000): Cryopreservation of Boar Semen. Studies on sperm viability in vitro and fertility. Doctoral thesis. Swedish University of Agricultural Sciences, Uppsala.

GIRAUD M.N., MOTTA C., BOUCHER D., GRIZARD G. (2000) Membrane fluidity predicts the outcome of cryopreservation of human spermatozoa. Human Reproduction, vol. 15, 10, $2160-2164$.

HOLT W.V. (2000): Basic aspects of frozen storage of semen. Animal Reproduction Science, 62, 3-22.

HUANG S.Y., KUO Y.H., LEE, W.C., TSOU, H.L., LEE Y.P., CHANG H.L., WU J.J. YANG P.C. (1999): Substantial decrease of heat-shock protein 90 precedes the decline of sperm motility during cooling of boar spermatozoa. Theriogenology, 51, 1007-1016. 
JOHNSON L.A. (1985): Fertility results using frozen boar spermatozoa: 1970 to 1985. In: Johnson L.A., Larsson K.Eds.: Deep Freezing of Boar Semen. Proc. 1st Int. Conf. Deep Freezing of Boar Semen Swedish Univ. Agric. Sciences, Uppsala, 199-222.

KOZUMPLÍK J., SOSNOVÁ J. (1985): The thermoresistance test of spermatozoa and fertility in bulls. Vet Med (Praha), 30, 7, 385-92.

KOZUMPLÍK J., ROUBAL M. (1990): Relation of heat resistance tests and sperm survival to pregnancy and fertility in sows. Vet. Med. (Praha), 35, 12, 725-32.

PAULENZ H., GREVLE I.S., ANDERSEN BERG K., THOMASSEN R. (1995): The use of dichromatic stain method (SpermacB) for determining changes in the acrosomal integrity of boar semen during cryopreservation. Reprod. Dom. Anim., 30, 1, 13-1 16.

SCHILLING E., VENGUST M. (1987): Frequency of semen colection in boars and quality of ejaculates as evaluated by the osmotic resistance of acrosomal membranes. Anim. Reprod. Sci., 12, 283-290.

SHAETZ F. (1963): Die künstliche Besamung bei den Haustieren, VEB Gustav Fischer Verlag, Jena.

THURSTON L.M., SIGGINS K., MILEHAM A.J. WATSON P.F., HOLT W.V. (2002): Identification of amplified restriction fragment lenght polymorphism markers linked to genes controlling boar sperm viability following cryopreservation. Biol. Reprod., 66, 3, 545-554.

VIANNA F.P., PAPA F.O., ZAHN F.S., MELO C.M., DELL'AQUA J.A. JR. (2009): Thermoresistance sperm tests are not predictive of potential fertility for cryopreserved bull semen. Anim Reprod Sci.,113, 1-4, 279-82.

WAGNER, H.G., TIBIER M., (2000): World statistics for artificial insemination in small ruminants and swine. Proc. 14fh ICAR, 2, 15:3.

WESTENDORF P., RICHTER L. TREU H. (1975): Zur Tiefgefrierung von Ebersperma. Labor- und Besamungsergebnisse mit dem Hiilsenberger Paillettenverfahren. Dtsch. Tierarztl. Wschr., 82, 261-267. 